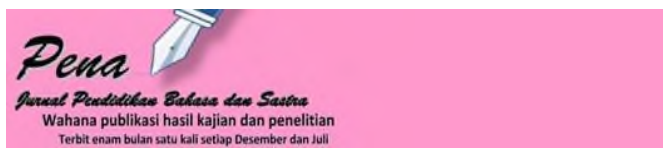

Vol. 7, No.2, Agustus 2018,

P-ISSN: 2089-3973, E-ISSN: 2615-7705

DOI: ttps://doi.org/10.22437/pena.v7i2.5701

\title{
Pengembangan Bahan Ajar Video Berbasis Kearifan Lokal pada Mata Kuliah Drama di FKIP Universitas Jambi
}

\author{
Larlen, Agus Salim, Liza Septa Wilyanti \\ PBSI FKIP Universitas Jambi \\ liza.septa@unja.ac.id
}

Penelitian ini berjudul "Pengembangan Bahan Ajar Video Berbasis Kearifan Lokal pada mata kuliah Drama di FKIP Universitas Jambi". Adapun tujuan dari penelitian ini dibagi menjadi dua aspek, (1) mendeskripsikan bentuk produk bahan ajar video berbasis kearifan lokal pada mata kuliah Drama di FKIP Universitas Jambi, (2) mendeskripsikan validitas, praktikalitas, dan efektivitas bahan ajar video berbasis kearifan lokal pada Mata Kuliah Drama di FKIP Universitas Jambi. Penelitian ini merupakan penelitian pengembangan yang mengikuti langkah ADDIE (analize, design, develop, implement, dan evaluate). Teknik pengumpulan data melalui observasi, kuesioner, dan tes. Data dianalisis menggunakan teknik analisis data deskriptif kualitatif dan kuantitatif. Berdasarkan hasil analisis data, hasil penelitian ini adalah sebagai berikut; (1) bentuk pengembangan bahan ajar video ber berbasis kearifan lokal pada mata kuliah Drama berisikan (a) pendahuluan atau teori pengantar oleh dosen pengampu, (b) video tampilan drama Orang Kayo Hitam: Asal-Usul Tanah Pilih Jambi karya Febrianiko Satria, (c) pembahasan teoretis tampilan drama Orang Kayo Hitam: Asal-Usul Tanah Pilih Jambi karya Febrianiko Satria yang telah disaksikan, (d) penugasan dan penutup oleh dosen pengampu. Setelah dilakukan uji validasi, dapat disimpulkan produk penelitian ini valid. Selanjutnya, produk penelitian juga telah diimplementasikan kepada mahasiswa dan dinyatakan praktis dan efektif.

Kata kunci: bahan ajar video, kearifan lokal, kursus drama

\begin{abstract}
Abstrack
This research entitled "Development of Video Teaching Materials Based on Local Wisdom in Drama Courses at FKIP Jambi University". The purpose of this study is divided into two aspects, (1) describe the form of video teaching materials based on local wisdom in the Drama Course in FKIP Jambi University, (2) describe the validity, practicality, and effectiveness of video teaching materials based on local wisdom in the course Drama at FKIP Jambi University. This research is a development research that follows the steps of ADDIE (analize, design, develop, implement, and evaluate). Data collection techniques through observation, questionnaires, and tests. Data were analyzed using qualitative and quantitative descriptive data analysis techniques. Based on the results of data analysis, the results of this study are as follows (1) the form of developing video teaching materials based on local wisdom in the Drama Course contains (a) introduction or introductory theory by lecturers, (b) video display of the drama Orang Kayo Hitam: Tanah Pilih Negeri Jambi,(c) theoretical discussion on the drama appearance of Orang Kayo Hitam: Tanah Pilih Negeri Jambi which was witnessed, (d) assignment and closing by the lecturer. After validation testing, it can be concluded that this research product is valid. Furthermore, research products have also been implemented for students and declared practical and effective.
\end{abstract}

Keywords: video teaching materials, local wisdom, drama courses 


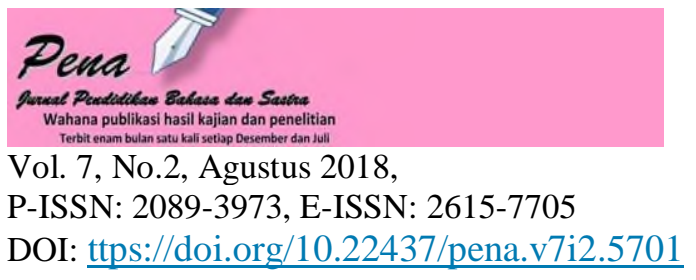

\section{PENDAHULUAN}

Sebagai salah satu daerah yang disebut-sebut merupakan pusat perkembangan dan pemerintahan kerajaan Sriwijaya pada masa lampau, Jambi memiliki banyak sekali kekayaan cerita rakyat. Cerita rakyat adalah suatu cerita yang hidup dan berkembang turun-temurun, dari satu generasi ke generasi berikutnya. Cerita rakyat adalah milik masyarakat pendukungnya. Cerita rakyat itu bisa disampaikan secara lisan dan disebut pula sastra lisan (oral literature). Sibarani (2012:20) memaparkan bahwa sekarang ini sebagian besar cerita rakyat itu tidak lagi mentradisi, tetapi masih potensial untuk direvitalisasi sebagai sumber kekayaan pluralisme etnik di tengah globalisasi kearifan. Cerita rakyat sebagai sastra lisan dan tradisi bercerita rakyat sebagai bagian dari tradisi lisan sama-sama penting untuk membuka kebebasan berpikir dan membangun kreativitas sebagai kekayaan kearifan etnik.

Salah satu cerita rakyat yang begitu melegenda di Jambi adalah legenda Orang Kayo Hitam, bahkan beberapa bukti sejarah pun membenarkan cerita rakyat yang hidup di tengah masyarakat Jambi itu benar-benar pernah terjadi dan bukan bualan semata. Dari penelitian Wilyanti (2014) diketahui bahwa legenda Orang Kayo Hitam memiliki kekayaan dari segi alur, tokoh, penokohan, dan nilai kearifan lokal Jambi. Hal ini tentu akan memperkaya khasanah bahan ajar berbau lokal di bidang akademik bila dapat dikembangkan sebagai bahan ajar berbentuk video.

Kearifan lokal adalah kebijaksanaan atau pengetahuan asli suatu masyarakat yang berasal dari nilai luhur tradisi budaya untuk mengatur tatanan kehidupan masyarakat (Sibarani, 2012). Pada masanya, nilai-nilai luhur ini menjadi pedoman dan acuan baik buruk bernilainya sesuatu hal. Menurut Ife dalam Sibarani, ada lima dimensi kultural tentang kearifan lokal, yaitu pengetahuan lokal, budaya lokal, keterampilan lokal, dan proses sosial lokal.

Sebagai salah satu bentuk kearifan lokal Jambi, cerita rakyat Orang Kayo Hitam memiliki konvensi budaya yang erat sebagai suatu bentuk karya sastra. Menurut Teew (2013: 78), '...pemahaman sebuah karya sastra tidak mungkin tanpa pengetahuan, sedikit banyaknya, mengenai kebudayaan yang melatarbelakangi karya sastra tersebut dan tidak langsung terungkap dalam sistem tanda bahasanya".

Salah satu yang menjadi ciri penanda implementasi KKNI dalam proses pembelajaran di tingkat perguruan tinggi adalah pembelajaran yang berpusat pada mahasiswa. Dalam hal 
ini, keaktifan dan penguasaan keterampilan khusus (bidang studi) adalah salah capaian pembelajaran yang harus dikuasai oleh mahasiswa. Oleh sebab itu, dosen atau pengajar di perguruan tinggi diharapkan dapat menggunakan berbagai bentuk instrumen, bahan, dan media pembelajaran yang dapat menunjang keaktifan dan pemahaman mahasiswa dalam proses pembelajaran. Pengembangan bahan ajar video berbasis kearifan lokal tidak hanya menuntut siswa pandai berdrama tapi lebih jauh mengenal dan ikut melestarikan budaya lokal.

Kurniasih, dkk (2014:56) mendefinisikan bahan ajar sebagai segala bentuk bahan berupa seperangkat materi yang disusun secara sistematis untuk membantu peserta didik dan pendidik/guru dalam melaksanakan kegiatan pembelajaran dan memungkinkan peserta didik untuk belajar. Lebih lanjut, (Zahroh, 2017) memaparkan bahwa bahan ajar merupakan segala bahan yang berisi materi dan telah disusun secara sistematis sehingga pembelajaran dapat berjalan dengan baik.

Tujuan pembuatan bahan ajar terdiri dari empat hal, yaitu: (1) membantu peserta didik dalam mempelajari sesuatu, (2) menyediakan berbagai jenis pilihan bahan ajar, sehingga mencegah timbulnya rasa bosan pada peserta didik (3) memudahkan peserta didik dalam melaksanakan pembelajaran, dan (4) Agar kegiatan pembelajaran menjadi lebih menarik. Manfaat pembuatan bahan ajar mengacu pada manfaat bagi pendidik dan peserta didik (Prastowo, 2014:2728).

Tomlinson (2011:2) menjelaskan bahwa bahan ajar pembelajaran bahasa dapat terfasilitasi melalui berbagai bahan. Bahan ajar dapat terdiri dari video, buku teks, DVD, YouTube, email, native speaker, intruksi pendidik/guru, dan lain sebagainya. Diantara berbagai bentuk bahan ajar tersebut, bahan ajar berbentuk video termasuk dalam katergori bahan pandang dengar. Bahan ajar pandang dengar memiliki beberapa kelebihan. 1) Mampu menunjukkan kembali gerakan tertentu, 2) penampilan peserta didik dapat dilihat kembali untuk dikritik atau dievaluasi, 3) memperkokoh proses belajar maupun nilai hiburan dari penyajian, 4) mendapatkan isi dan susunan yang masih utuh dari materi pelajaran atau latihan, 5) informasi dapat disajikan secara serentak pada waktu yang sama, di lokasi yang berbeda, dan jumlah peserta (penonton) yang tidak terbatas, dan 6) pembelajaran dengan video merupakan suatu kegiatan pembelajaran yang mandiri. 


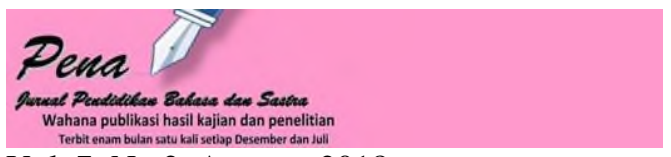

Vol. 7, No.2, Agustus 2018,

P-ISSN: 2089-3973, E-ISSN: 2615-7705

DOI: ttps://doi.org/10.22437/pena.v7i2.5701

Menurut Nuryanto (2017), pembelajaran sastra, khususnya drama saat ini masih menitikberatkan pada aspek kognitif dan pengetahuan saja. Akibatnya, para siswa ataupun mahasiswa hanya mampu menghafalkan istilah-istilah saja. Hal ini tentulah bukan sesuatu yang menggembirakan mengingat mahasiswa Prodi Bahasa dan Sastra Indonesia FKIP Unja nantinya akan menjadi calon guru yang dituntut untuk dapat mengajarkan sastra, termasuk di dalamnya berdrama, kepada peserta didiknya.

Untuk itu, dirasa perlu bagi dosen pengampu untuk mengembangkan bahan ajar video pada mata kuliah drama guna meningkatkan sikap positif dan keterampilan mengapresiasi drama di kalangan mahasiswa Prodi Bahasa dan Sastra Indonesia FKIP Unja. Adapun bahan ajar video yang akan dikembangkan pada mata kuliah drama nantinya berisi materi pengantar dan contoh penampilan drama yang mengangkat kearifan lokal Jambi.

\section{METODE PENELITIAN}

Penelitian pengembangan bahan ajar video berbasis kearifan lokal pada mata kuliah Drama di FKIP Universitas Jambi ini termasuk ke dalam jenis penelitian Research and Development atau penelitian dan pengembangan. Penelitian ini mengadopsi model ADDIE (analyse, design, develop, implement, and evaluate) yang dikembangkan oleh Robert Maribe Branch.

Metode penelitian pengembangan digunakan untuk menghasilkan produk tertentu (Sugiyono, 2010:407). Penelitian ini tergolong penelitian pengembangan suatu produk pendidikan. Hal ini sejalan dengan pendapat yang dikemukakan oleh Borg dan Gall (Setyosari, 2015: 276) "Penelitian pengembangan merupakan suatu proses yang dipakai untuk mengembangkan dan menvalidasi produk pendidikan.”

Adapun desain penelitian pengembangan (research \& development) akan dilakukan seperti tampak pada pada desain berikut. 


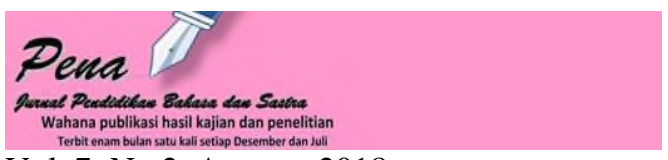

Vol. 7, No.2, Agustus 2018,

P-ISSN: 2089-3973, E-ISSN: 2615-7705

DOI: ttps://doi.org/10.22437/pena.v7i2.5701

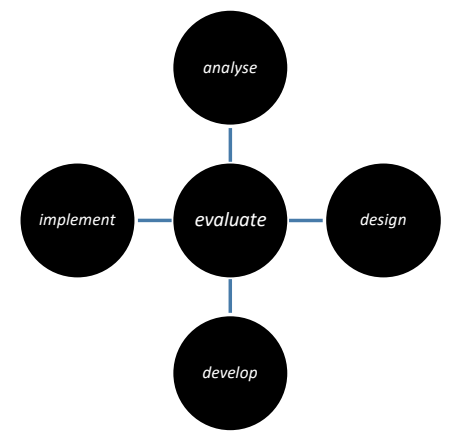

Gambar Desain Penelitian Pengembangan ADDIE (Branch, 2009:2)

Deskripsi rancangan penelitian sesuai dengan gambar di atas adalah sebagai berikut.

1. Analyze. Pada tahap awal ini, peneliti melakukan identifikasi pada setiap permasalahan yang dihadapi. Peneliti menganalisis hasil evaluasi perkuliahan Drama pada semester yang lalu. Selain itu, dilakukan wawancara awal untuk mengetahui kesulitan yang dihadapai mahasiswa dalam proses pembelajaran.

2. Design

Setelah dilakukan analisis proses dan hasil pembelajaran pada mata kuliah Drama sebelumnya, peneliti mulai merancang model video bahan ajar yang baru. Keunggulan dan kekurangan model pembelajaran yang lama juga menjadi bahan pertimbangan peneliti.

\section{Develop}

Pada tahap ini, peneliti mulai mengembangkan draf model video bahan ajar, perekaman video bahan ajar, dan instrument penilaian. Dalam mengembangkan video bahan ajar ini, peneliti menggunakan bahan ajar berbasis nilai kearifan lokal. Peneliti mengembangkan cerita rakyat Orang Kayo Hitam: Asal-Usul Tanah Pilih Jambi yang telah dihasilkan dari penelitian terdahulu untuk dihasilkan menjadi bentu baru, yakni naskah drama yang kemudian direkam menjadi bahan ajar video drama.

\section{Implement}

Bahan ajar video berbasis kearifan lokal yang telah direkam dan disusun diimplementasikan kepada mahasiswa yang telah mengontrak mata kuliah Darama. Pengimplementasian ini untuk mengetahui praktikalitas dan efektivitas penerapannya dalam pembelajaran. 


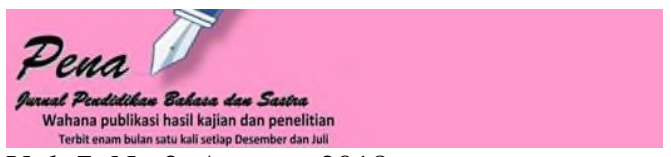

Vol. 7, No.2, Agustus 2018,

P-ISSN: 2089-3973, E-ISSN: 2615-7705

DOI: ttps://doi.org/10.22437/pena.v7i2.5701

\section{Evaluate}

Pada tahap akhir ini, dilakukan evaluasi terhadap bahan ajar yang telah coba diimplementasikan kepada mahasiswa. Bahan ajar juga akan divalidasi oleh ahli desain pembelajaran.

Penelitian ini dilaksanakan di kampus Program Studi Pendidikan Bahasa dan sastra Indonesia FKIP Universitas Jambi. Jenis data yang diambil pada penelitian ini adalah data kualitatif dan kuantitatif. Kualitatif didapat melalui observasi dan wawancara, sedangkan data kuantitatif didapat dari hasil tes mahasiswa menganalisis unsur-unsur intrinsik dalam drama yang disaksikan. Sumber data dalam penelitian ini adalah mahasiswa yang mengontrak mata kuliah Drama pada semester II. Untuk mengumpulkan data penelitian, peneliti menggunakan instrumen pedoman wawancara, pedoman observasi, dan kuesioner.

Analisis data hasil penelitian dilakukan untuk mengetahui validitas, praktikalitas, dan efektivitas perangkat pembelajaran yang telah dibuat. Validitas model video bahan ajar yang telah dikembangkan diperoleh dari tingkat pencapaian responden. Data dikumpulkan melalui kuesioner dan diolah dengan rumus persentase. Praktikalitas dan efektivitas video bahan ajar berbasis kearifan lokal diketahui dari praktisi yang telah ditentukan berdasarkan kriteria.

Tingkat Pencapaian $=\underline{\text { skor }- \text { rata }}$ X 100\%

Skor Ideal

\section{HASIL DAN PEMBAHASAN}

Berdasarkan pengalaman dan hasil observasi, langkah-lamgkah pembelajaran drama dimulai dari membuka pelajaran, selanjutnya bagian inti mahasiswa berpresentasi di kelas, tanya jawab penyaji dan peserta diskusi kelas, penyaji menutup sesi diskusi, dosen meyampaikan beberpa hal yang dianggap kurang lengkap atau belum tepat terkait penyajian maupun diskusi tanya jawab mahasiswa, terakhir menutup pembelajaran. Langkah-langkah di atas berlangsung dari pertemua 1-7. Pertemuan selanjutnya, 9-15 mahasiswa diminta untuk berpraktik berlatih bermain drama dan akan dipentaskan di akhir semester.

Dari langkah-langkah pembelajaran tersebut, beberapa peran dosen yang terlihat adalah sebagai penyampai pesan atau materi pembelajaran, pemberi motivasi dalam bentuk memberikan contoh-contoh, memberikan fasilitas selama pembelajaran berlangsung, dan 
pelatih dalam berlatih bermain drama. Di pihak mahasiswa, mereka berperan aktif dalam diskusi, baik sebagai penyaji maupun peserta diskusi, mengamati dosen mengajar di depan kelas, menjadi model aktor/aktris atau peran pendukung lainnya dalam berlatih dan bermain drama.

Prinsip reaksi yang terlihat dari peran-peran mahasiswa tersebut dipandang dosen masih belum efektif dan termotivasi. Hal tersebut disebabkan oleh materi presentasi yang telah dianalisis memperlihatkan beberapa hal yang belum baik dan benar, seperti materi yang berasal dari sumber yang kurang akurat dan tidak lengkap, tidak ada contoh-contoh yang mampu menggambarkan materi-materi tersebut secara konkret, dan ketidakmampuan mahasiswa menjawab beberapa pertanyaan peserta diskusi dalam penyajian materi.

Sistem penunjang dalam pembelajaran drama yang digunakan selama ini adalah buku cetak dan ringkasan materi dari dosen. Belum ada media pembelajaran, baik yang berbasis kearifan lokal maupun yang menggunakan teknologi, dalam pelaksanaan pembelajaran. Dengan melaksankan pembelajaran secara konvensional, mahasiswa kurang mampu menguasai materi dan keterampilan bermain drama kurang maksimal.

Pengembangan bahan ajar pada hakikatnya disesuaikan dengan capaian pembelajaran yang tertuang dalam RPS pembelajaran. Capaian pembelajaran Drama, yaitu: 1) memiliki kemampuan memahami konsep pengertian drama, hakikat drama yang membedakannya dari karya sastra lainnya; 2) mampu mementaskan drama; dan 3) memiliki sikap yang baik dalam pembelajaran drama.

Dengan melihat kekuatan dan kelemahan model pembelajaran konvensional yang telah diterapkan oleh dosen pada semester sebelumnya, desain bahan ajar video yang akan dikembangkan adalah sebagai berikut. Pertama, langkah-langkah atau sintak dalam pembelajaran drama harus mencerminkan capaian pembelajaran mata kuliah Drama. Keaktifan mahasiswa melalui presentasi materi di kelas memang diperlukan. Namun, ketepatan materi, sumber yang digunakan, dan contoh yang dipelajari harus lebih diperhatikan. Untuk itu, peneliti akan menggunakan bahan ajar video berbasis kearifan lokal sebagai salah satu bahan ajar. Penggunaan bahan ajar video diharapkan dapat lebih meningkatkan pemanfaatan media teknologi dalam pembelajaran. Selain itu, video yang digunakan akan menggunakan cerita atau naskah yang bernilai kearifan lokal. Hal tersebut sesuai dengan apa yang diinginkan dalam kurikulum KKNI agar tetap mengandung nilai-nilai 


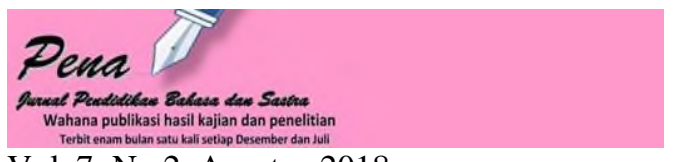

Vol. 7, No.2, Agustus 2018,

P-ISSN: 2089-3973, E-ISSN: 2615-7705

DOI: ttps://doi.org/10.22437/pena.v7i2.5701

kearifan lokal. Selain itu, pemilihan naskah yng bernilai kearifan lokal juga sebagai usaha untuk merevitalisasi dan melestarikan kekayaan sastra daerah di Jambi.

Kedua, pada bahan ajar video yang akan dikembangkan diatur tentang hubungan dosen dengan mahasiswa sesuai dengan capaian pembelajaran yang diinginkan. Dosen harus mampu merancang hubungan dengan mahasiswa secara baik mengingat beberpa perannya yang penting. Pertanyaan seperti apa saja peran dosen, apa saja peran mahasiswa, dan bagaimana dosen memotivasi mahasiswa agar aktif dan memiliki pemahaman yang baik terkait drama adalah tiga potensi yang harus terjawab.

Ketiga, bahan ajar video berbasis kearifan lokal yang akan dikembangkan merupakan sitem penunjang yang akan digunakan oleh dosen kepada mahasiswa. Untuk itu, salah satu prinsip keberhasilan yang harus ditanamkan dosen kepada mahasiswa adalah pikiran positif. Jika dosen memiliki berpikiran positif terhadap mahasiswa dan memandang mahasiswa memiliki potensi untuk berkembang maka bahan ajar video berbasis kearifan lokal ini dapat digunakan sebagai media pembelajaran yang efektif.

Keempat, efek dari penggunaan video bahan ajar ini nantinya diharapkan mahasiswa dapat memahami capaian pembelajaran yang diinginkan dalam pembelajaran mata kuliah Drama, menguasai materi drama, menguasai teknik bermain drama, dan bersikap positif dalam proses pembelajaran drama.

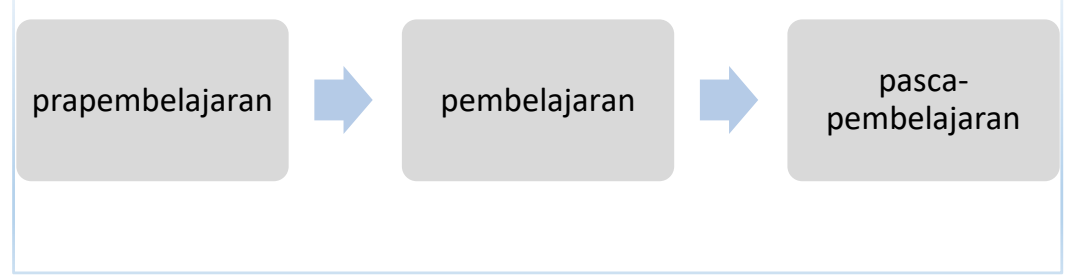

Pada proses pengembangan terdapat tiga proses atau tahap yang dilakukan oleh peneliti. tahap prapembelajaran, peneliti melakukan pemilihan naskah cerita yang dianggap bernilai kearifan lokal. Naskah Legenda Orang Kayo Hitam: Asal-Usul Tanah Pilih dipilih untuk dikembangkan menjadi naskah drama karena telah terbukti pada penelitian terdahulu mengandung nilai kearifan lokal yang sesuai dengan budaya Jambi.

Naskah Legenda Orang Kayo Hitam: Asal-Usul Tanah Pilih dikembangkan menjadi bentuk naskah drama untuk kemudian dipentaskan dan dilakukan perekaman. Aktor dan aktris dipilih oleh sutradara untuk berlatih memerankan karakter sesuai naskah drama yang 


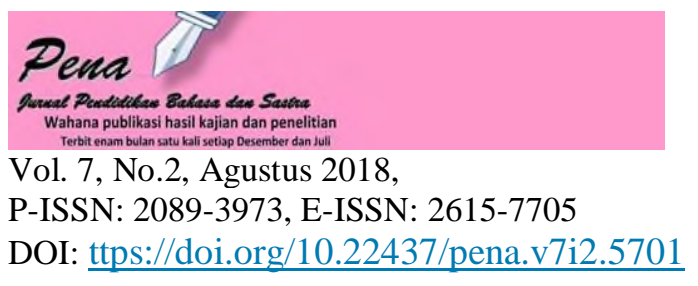

ada. Pada tahap ini, penulis melibatkan mahasiswa Prodi Pendidikan Bahasa dan sastra Indonesia FKIP Unja untuk berperan sebagai sutradara, pemain, tim tata rias, kostum, dan tata panggung.

Setelah melalui proses latihan sesuai dengan waktu yang telah dijadwalkan, dilakukan perekaman atau pengambilan gambar oleh tim produksi. Seluruh tim produksi yang terlibat dalam pembuatan bahan ajar video ini juga adalah mahasiswa Prodi Pendidikan Bahasa dan sastra Indonesia FKIP Unja. Terdapat dua bagian video yang disusun dalam penelitian ini, yaitu video 1 yang berisi penampilan drama Orang Kayo Hitam: Asal-Usul Tanah Pilih dan video 2 yang berisi pengantar, materi, dan tugas perkuliahan.

Selanjutnya tahap pengembangan dilakukan saat pembelajaran berlangsung. Cara konvensional yang sebelumnya hanya mengandalkan materi presentasi diubah menjadi menyaksikan videdo pembelajaran terlebih dahulu. Pada video yang disaksikan terdapat beberapa hal yang harus dilakukan mahasiswa. Pada proses pembelajaran mahasiswa harus memahami pengantar dan materi serta tugas yang disampaikan oleh dosen. Kemudian pada video 2, mahasiswa harus mencatat hal-hal terkait materi pada video 1 .

Tahap terakhir adalah prapembelajaran. Pada tahap ini, mahasiwa harus menyerahkan laporan analisis dari bahan ajar video yang disaksikannya. Selanjutnya peneliti dapat melakukan analisis terhadap hasil pemahaman mahasiswa dari video yang telah disaksikannya. Kevalidan, kepraktisan, dan keefektifan bahan ajar video selanjutkan akan diuji oleh peneliti secara saksama.

Tahap keempat pada penerapan model ADDIE adalah implementasi. Pada proses pemebelajarannya, mahasiswa diminta untuk menyaksikan video I terlebih dahulu. Video I berisi pengantar dan materi dari dosen terkait materi pembelajaran. Kemudian dalam video tersebut dosen juga menyampaikan hal-hal yang harus dilakukan pada saat menyaksikan video pementasan pada video 2 .

Pada tahap evaluasi, peneliti melakukan uji validitas, praktikalitas, dan efektivitas terhadap bahan ajar video berbasis kearifan lokal. Berdasarkan penilaian tiga orang validator, kualitas audio visual memperoleh nilai 4,3. Bagian pendahuluan memperoleh nilai 4,7. Bagian isi memperoleh nilai kisaran 4 sampai 5. Bagian penutup memperoleh nilai kisaran 4 sampai dengan 4,7. Secara keseluruhan, nilai rata-rata yang diperoleh adalah 4,3. Angka ini menunjukkan bahan ajar video berbasis kearifan lokal layak dan valid untuk digunakan. 
Hasil penilaian dari 8 orang mahasiswa sebagai praktisi tentang bahan ajar video berbasis kearifan lokal yang mencakup langkah-langkah, materi, sistematika penyajian, dan nilai kearifan lokal yang terkandung didalamnya memperoleh nilai baik dengan rata-rata 4,3. Dari hasil tersebut dapat disimpulkan bahwa bahan ajar video berbasis kearifan lokal yang telah dikembangkan tergolong praktis.

Berdasarkan hasil analisis data, kemampuan mahasiswa dalam menganalisis unsur intrinsik dalam drama yang disaksikan pada bahan ajar video berbasis kearifan lokal tergolong sangat baik, yaitu 81,9. Berdasarkan peraturan FKIP Unja, nilai KKM adalah 70. Artinya, semua mahasiswa dinyatakan tuntas dan penerapan bahan ajar video berbasis kearifan lokal tergolong efektif.

\section{SIMPULAN}

Bahan ajar video berbasis kearifan lokal yang telah dikembangkan terdiri dari dua bagian, yaitu video 1 dan 2. Video 1 berisikan (a) identitas bahan ajar, (b) pendahuluan, (c) isi, dan (d) penutup. Video 2 berisi rekamana penamiplan drama Orang Kayo Hitam: AsalUsul Tanah Pilih Jambi.

Pada video 1 bagian identitas bahan ajar, peneliti memaparkan nama mata kuliah, jumlah SKS, dosen pengampu, waktu pembelajaran, dan materi ajar yang terdapat dalam bahan ajar video. Bagian pendahuluan berisi pengantar dari dosen tentang pementasan sebagai penafsiran kedua dan drama sebagai pertunjukan serta unsur yang mendukung drama. Pada bagian ini juga dosen memberikan sedikit gambaran mengenai peran sutradara, pemain, teknisi, dan penonton, pentas dan komposisinya, kostum, tata rias, pencahayaan, dan tata musik.

Bagian terpenting pada video 1 ini adalah bagian isi. Pada bagian isi, dosen memberikan pemahaman yang cukup kepada mahasiswa terkait proses pementasaan drama, mulai dari membentuk kelompok, memilih naskah, dan mengatur jadwal dan pola latihan. Video 1 diakhiri dengan bagian penutup yang berisi tugas individu kepada mahasiswa. Tugas dikaitkan juga dengan materi yang akan datang.

Pada video, mahasiswa diminta untuk menyaksikan penampilan drama Orang Kayo Hitam: Asal-Usul Tanah Pilih Jambi. Pada dasarnya, mahasiswa tidak hanya sekadar menyaksikan penampilan drama saja. Lebih jauh, mahasiswa diminta menganalisis unsur- 


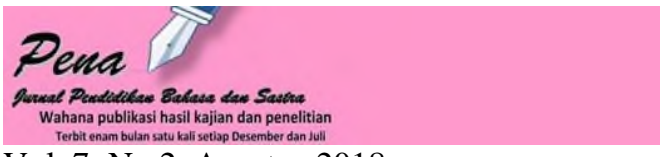

Vol. 7, No.2, Agustus 2018,

P-ISSN: 2089-3973, E-ISSN: 2615-7705

DOI: ttps://doi.org/10.22437/pena.v7i2.5701

unsur intrinsik yang terdapat pada drama Orang Kayo Hitam: Asal-Usul Tanah Pilih Jambi tersebut.

Bentuk bahan ajar video berbasis kearifan lokal ini disarankan oleh peneliti untuk digunakan dalam perkuliahan drama karena telah terbukti memudahkan mahasiswa dalam memahami materi drama, meningkatkan rasa cinta terhadap karya sastra daerah yang mengandung nilai kearifan lokal, dan meanfaatkan media teknologi yang ada.

\section{DAFTAR RUJUKAN}

Branch, R.M. 2009. Instructional Design The ADDIE Approach . New York: Springer.

Hainuatus Zahroh, "Pengembangan Model Bahan Ajar Video Kreatif Terpimpin Edukatif (KTE) untuk Pembelajaran Menulis Karya Ilmiah Sederhana Peserta Didik Kelas IX SMP Mamba'unnur Bululawang," Jurnal Inovasi Pembelajaran, Volume 3, Nomor 1 (Mei 2017).

Kurniasih, Imas, dan Berlin Sani. 2014. Panduan Membuat Bahan Ajar Buku Teks Pelajaran. Surabaya: Kata Pena.

Liza Septa Wilyanti, “Kajian Struktur dan Nilai Budaya dalam Legenda Orang Kayo Hitam di Jambi dan Pemanfaatannya sebagai Alternatif Bahan Ajar Kajian Prosa Fiksi di FKIP Universitas Jambi,” Tesis Universitas Pendidikan Indonesia, Bandung, 2014.

Nuryanto, Tato. 2017. Apresiasi Drama. Depok: Rajagrafindo Persada.

Prastowo, Andi. 2014. Panduan Kreatif Membuat Bahan Ajar Inovatif. Jogjakarta: Diva Press.

Ristekdikti. 2015. Kerangka Kualifikasi Nasional. Jakarta. Direktorat Jendral Pembelajaran dan Kemahasiswaan Kementrian Riset, Teknologi, dan Pendidikan Tinggi Republik Indonesia.

Setyosari, Punaji. 2015. Metode Penelitian Pendidikan dan Pengembangan. Jakarta: Prenadamedia Group.

Sibarani, R. 2012. Kearifan lokal: hakikat, peran, dan metode tradisi lisan. Jakarta: Asosiasi Tradisi Lisan.

Sugiyono, 2010. Metode Penelitian Pendidikan. Bandung: Alfabeta.

Teeuw, A. 2013. Sastra dan ilmu sastra. Jakarta: Pustaka Jaya.

Tomlinson, Brian. 2011. Materials Development in Language Teaching. UK: Cambridge University Press. 